it would be especially desirable to obtain regular observations of the time and height of high and low water on the coasts, \&c., according to the rules, and on the plan, proposed by $\mathrm{Mr}_{\mathrm{r}}$. Whewell, in his late researches on this subject."

$M_{\text {ag. Pop. Scí. }}$

\title{
On the Stony Matters which are employed in China in the time of Famine, under the name of Flour of Stone. By M. Biот.
}

The details which were communicated to the Academy of Sciences by M. Je Humboldt concerning the existence of a stony substance, which is sometimes employed in Lapland, in the time of dearth, have recalled to my recollection the notice of a similar fact which has lately reached us from China, and which was reported in the correspondence of the missionaries. My son having likewise found the same fact, attested at many different periods in the Japanese Encyclopédia, with the dates atlached, I requested him to translate the passages wbich related to the subject; and it has occurred to me that the Academy would regard with interest the collection of these documents concerning the employment of the article in a way much more general than we are usually led to believe.

The Japanese Encyclopedia, book Ixi., "Upon Stones and Minerals," contains an article entitled Chi Mien or Slone-fiour, of which we now present a translation; and in which it will be secn the same superstitious ideas prevail which $M$. de $I 1$ umboldt had remarked in Laponia. "The Pen-tsaoKong-mou"* remarks, "The flour of stone is not an ordinary substance, but a miraculons production. Many declare that it is produced in the time of fumine. Under the Emperor IIien-T'song, of the dynasty of Tang, in the period of Tien pao, the third year (answering to A. D. 744,) a miraculous spring issued from the earth, and stones were decomposed and converted into flour." 'To the letter-press of this extract is conjoined a wood-cut, which represents the spring issuing forth in cascides, and the stones breaking up into slender threads, but these are so incorreclly indicated that it is not possible to draw any mineralogical inferences.

We subjoin some additional notices. "Under the Emperor of HianTsong, of the same dynasty, in the period Yuen-ho, fourth year (A. D. 809, ) stones were decomposed and became meal." Under the Emperor Tching: Tsong, of the dynasty of Soung, in the period Tsiang-fou, fifth year (A. D. 1012, "a marrow was produced from stones which resembled flour." Under Jin-Tsong, in the period Kia-yeou, seventh year (A. D. 1062, "the flour of stone was produced." Under Tchi-Tsong, in the period Fuenfong, third year (A. D. 1080,) "stones were decomposed and became llour. All these kinds of flour were collected and eaten by the poor."

We now add the statement, made in 1834, by one of the Chinese missionaries, M. Mathieu-Ly, who is established in the province of Kiang-Si.t The facts which he describes relate to the same year 1834, and to the three

* This work is a collection of Chinese Natural History, compiled about A. D. 1575, from treatises which were still more ancient. M. S. Julien having kindly communicated to my son his copy of the Pen-tsao-Kangmon, the quotation given in the Japanese Encyctopedia has been compared with the original text, and found to be accurate. Many of the places named are situated in the Northern Province called Chan-Si, where, the cold is often severe during the winter; others belong to the maritime province of Chan-tong and Kiang-Nan, near the mouth of the Yellow River. The provinces of Hot -Koulang and Kiang-Si, concerning which the missionaries attest the same fact, are different from these, and are situated in the valley of the Blue River.

t See Annales de la propogation de la Foi, No. xlviii, p. 85, Sept. 1836. 
preceding, so that they coincide with those mentioned by M. Retzins re. garding Laponia. "Many of our converts will assuredly die this year from want; and it is God alone who can provide a remedy for so many and such aggravated necessities; all the crops have again been carried away by the overflowing of the rivers. For a period of three years now, an immense number of persons have supported themselves upon the bark of a tree which is found in the country; whilst others eat a light earth of a white colour, which has been discovered in a mountain. The earth can only be bought with silver, and it is not every one that can procure it. These wretched people first sold their wives, their sons and daughters, they then sold their tools, and the furniture of their houses; and even these they have finally demolished that they might sell the timber-work. Many of these unfortunate people were really rich four years ago."

Another missionary, M. Rameaux, ${ }^{*}$ writing concerning the province of Hon-Kouang, about the middle of the year 1834, supplies details which are not less deplorable. "The district Fan-Hien, he remarks, contained about a thousand converts; but their number has been exceedingly reduced by famine. A great number have come to me to demand the last sacraments. 'They calculate their resources, and accurately know, almost to an hour, the number of days they can subsist. They receive the sacrament of extreme unction when their means are exhausted, and then having notbing to eat, they calmly wait the moment of their demise.".

Clearly to apprehend the cause of these calamities, and their frequent returns among an industrions society, which is chiefly agricultural, and bas had the blessing of a steady government for a long course of ages, it is ne. cessary to recollect that many provinces of China, more extensive than the half of the whole kingdom of France, are great uniform plains, traversed by immense rivers, whose beds are ever and anon choked up by the deposits which are left by the waters, so that it is necessary constantly to contne them by high dikes, which are maintained with immense labour. The provinces of Hou-Kouang and of Kiang-Si, for example, which have now been named, are thus traversed by the Blue and other great rivers. These circumstances afford every facility for irrigation, develop an agriculture in which industry is pushed very nearly to its limit, whereby the most abundant harvests are produced, especially of rice, which is cultivated even up the slopes of the hills, the water being forced up by hand-engines. So long as this state of things continues, the necessary result is an immense production of the means of subsistence, which leads to a corresponding development of the population. But if once the waters so far increase as to run over the dikes, they spread over the plain, inundate it, and swallow up a portion of the population: whilst those who escape the disaster, finding themselves ruined, and deprived of all their resources solong as the waters cover the soil, remain a prey to all the miseries which the missionaries describe, and, finally, in immense numbers, actually perish from hunger. This cause, conjoined with the awfinl catastrophes produced by earthquakes, which seem to be more frequent, more violent, and especially more widely spread in China than in most other regions of the globe, enables us, in a great degree, to understand the sudden vicissitudes which, as the history of China attests, so often occur in the number of the population of this vast empire; vicissitudes whose proportionate number bears no relation to the regular

* Ann. de la propogation de la Foi, No, xlyuii, p. 61. 
law of European population, as may be seen in a memoir inserted in the Journal de la Société Asiatique**

Fit. New Philos Jour.

\section{On the Organic remains in the Coal Formation at Wardie, Scotland. By Robt. Paterson, M. D.}

It is now almost universally admitted, that coal bas resulted from the distribution of vegetable remains over areas of grenter or less extent upon a previously deposited surface of sand, or argillaceous silt, and that after the entombment of this mass of vegetable matter, other layers of mud and clays were deposited on it; and this operation must have continued for a considerable length of time, during which it is more than probable that an abundant vegetation existed at no great distance from the spot where this process was taking place.

'These changes are most likely to have gone on in estuaries or indenta. fions of the land, into which this mass of vegetable matter was brought by rivers, while the sea made occasional, or in some instances continunus, incursions. In this manner we can easily see how, hy accidental circumstances, the productions of the land or sea in greater or less abundance are occasionally met with in the strata of the carbonilerous series, and how in one coal district an examination of its organic remains may afford one individual reason to believe, that the strata were chielly deposited in salt water; a second, from the examination of a different locality, that they are entirely fluviatile, or probably he may imagine them lacustrine; while a third may see the same organic remains which have given rise to the two former opinions so mixed up and incorporated together in another place, as to leave no doubt on his mind that the two former cases were only extreme degrees of what he had noticed.

Ibid.

"An account of a Well at Beaumont Green in the County of Hereford fifteen miles from London, about a mile to the west of the roud to Ware;" by J. Mitoheli, LL. D., F. G. S.

This well was dug in 1833, in the premises of Mr. Munt, a magistrate of the county, and the information respecting it obtained from two gentlemen accustomed to collect evidence with the strictest scrutiny.

The strata passed through, were one foot regetable mould, 15 feet gravel, one foot sand with flints, 83 feet gravel clay, 15 feet blue sand with black pebbles, 10 feet blue clay, $1 \frac{1}{2}$ feet fine soft white sand, or $126 \frac{1}{3}$ feet down to the chalk, which was penetrated for 40 feet, when a spring was met with; but the digging continued 17 feet lower to form a reservoir of water, and this was favoured by making the excavation in the chalk of a bell shape, but above this the well was $4 \frac{1}{2}$ feet in diameter.

When the well was dug the weather was dry, but on this becoming very wet the 15 feet stratum of blue sand and black pebbles began to emit loul air, by which one of the well-diggers was suffocated in descending. A hawk flying over the well fell into it, and a similar fate befell smaller birds, also wasps, bees and flies. On closing up the mouth of the well, with the exception of an orifice an inch in diameter, so powerful was the force of the issuing current of foul air that it raised a weight of twelve ounces of lead.

- Memoire sur la population de la Chine et ses Variations, depuis l'an. 2400 avant l'ère Chrètienne, jusquáa $13 \mathrm{e}$ Siècle après; par Eduurd Biot. 